\title{
Participation in Divine Light and Church Membership in De Spiritu Sancto of Basil of Caesarea
}

\author{
HARri HuOvinen ${ }^{*}$
}

The imagery of light plays a key role in Basil of Caesarea's narrative of God and salvation. Curiously, the communal aspects of this imagery have received little attention in scholarship. A systematic analysis of De Spiritu Sancto reveals that in Basil's understanding, participation in divine light functions as a parallel concept to Church membership. To begin with, the corporate nature of participation in divine light is evident from the ecclesial rites of initiation whereby this participation is bestowed. Furthermore, Basil uses the imagery of light to underscore the corporate nature of both the mystical union between God and the baptized, and the outward expressions of the believers' lives in the divine light: worship and public witness. In addition to shedding new light on the Basilian notion of Church membership, the study offers a fresh outlook into the ecumenical dialogue between the Orthodox Church and Lutheran Church bodies on the theology of initiation.

Keywords: Light, illumination, Church membership, ecclesiology, Patristic; Basil of Caesarea

\section{Introduction}

As is well known, images of light and illumination appear frequently in the works of Basil of Caesarea. ${ }^{1}$ In much of Eastern and Western theology, such imagery has been primarily analyzed in the context of the personal mystical experience, or the individual spiritual perception ${ }^{2}$. This tendency appears to have influenced many scholars of Basil, to the extent that in studies covering his use of these images, the inquiry into their communal aspects is often left

\footnotetext{
* Harri Huovinen, PhD candidate, Systematic Theology and Patristics, School of Theology, University of Eastern Finland, Töyrykatu 3 A 20, 15140 Lahti, Finland, harrihu@student. uef.fi.

${ }^{1}$ For instance, De Spiritu Sancto contains more than fifty instances of words related to light. The final count obviously depends on how this relatedness to light is interpreted. For the record, there are 22 occurrences of the noun $\varphi \tilde{\omega} \varsigma$ in its different inflections. As for the $\varphi \omega \tau-$ verbs, the count is eight, whereas the noun $\varphi \omega \tau \iota \sigma \mu$ ó $\varsigma$ appears four times in different forms. There is only one instance of $\varphi \omega$ - adjectives. Basil also employs other light-related vocabulary, such as - $\lambda \alpha \mu$ - verbs (8 instances), and words of the $\lambda \alpha \mu \pi$ - group (4). Additionally, there

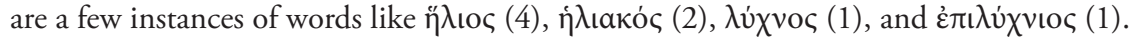

${ }^{2}$ This appears to be a part of a broader trajectory in Christian mystical theology. For a recent example of this general tendency, see: Edward Rommen, Being the Church: An Eastern Orthodox Understanding of Church Growth (Eugene, OR: Cascade Books, 2017), 98, 153.
} 
somewhat cursory ${ }^{3}$. On the other hand, in notable studies covering Basil's ecclesiology, the inquiry into his use of the imagery of light is absent altogether. ${ }^{4}$ I contend, however, that in Basil's understanding, the participation in divine light is inseparable from Church membership.

The aim of this article is to answer the following question: In $D e$ Spiritu Sancto, what is the nature of the relationship between participation in divine light and Church membership? Answering this question will not only shed new light on Basil's notion of Church membership, but it will also aid in filling the aforementioned gap in previous scholarship.

To reach these goals, the following steps will be taken: The first section concentrates on general observations of the main themes of this study. I will start by examining the functions of light-related imagery in Basil, and continue by providing a brief outline of his general notion of Church membership. After this, in the main part of the study, the ecclesial nature of divine illumination will be analysed from the perspectives of Christian initiation, communal life in the Church, and the outward expressions of life in divine light. Having completed the main analysis, I will propose an ecumenical implication that the present discussion offers to the dialogue between the Eastern Orthodox Church and Lutheran Church bodies. Lastly, some concluding remarks will be given.

\section{Imagery of Light and Church membership in Basil: general observations}

\section{The Functions of Light-Related Imagery}

In Basil's oeuvre, the imagery of light is first and foremost a means of depicting God. ${ }^{5}$ At times, he refers to God in general by employing vocabu-

\footnotetext{
${ }^{3}$ This is apparent in Timothy P. McConnell's recent study Illumination in Basil of Caesarea's Doctrine of the Holy Spirit (Minneapolis: Fortress Press, 2014), see e.g.: 66, 220. See also: Olga A. Druzhinina, The Ecclesiology of St. Basil the Great: A Trinitarian Approach to the Life of the Church (Eugene, OR: Pickwick Publications, 2016), 93-94.

${ }^{4}$ See e.g.: Paul Jonathan Fedwick, The Church and the Charisma of Leadership in Basil of Caesarea (Toronto: Pontifical Institute of Mediaeval Studies, 1979); Lukas Vischer, Basilius der Große: Untersuchungen zu einem Kirchenvater des vierten Jahrhunderts (Basel: Buchdruckerei Friedrich Reinhardt AG, 1953). Vischer (33) does quote one passage where Basil (Exh. bap. 5, PG 31, 433), echoing Cyril of Jerusalem (Procatech. 16; Wilhelm Karl Reischl and Joseph Rupp, eds., Cyrilli Hierosolymarum archiepiscopi opera quae supersunt omnia, vol. 1

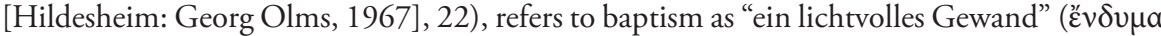
$\varphi \omega \tau \varepsilon เ v o ́ v)$. However, the scholar offers no further exposition on this topic.

${ }^{5}$ In this, Basil joins the chorus of Greek writers and earlier Christian authors, for whom light is a symbol of divinity and life. In philosophers, the theme appears e.g. in Plato, see: Resp. VI 508a; Tim. 39e-40a, Ioannes Burnet, ed., Platonis Opera VI (Oxonii: E Typographeo
} 


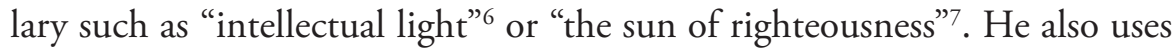
light-related imagery, more specifically in reference to the Persons of the Trinity. For instance, he may refer to the Father as a "light without beginning" ${ }^{\text {, }}$ or invoke the second Person of the Trinity, i.e., "the Creator Word,

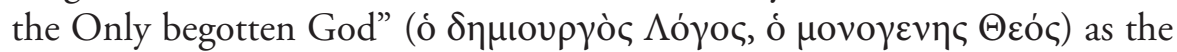

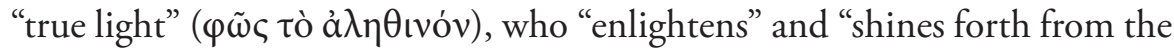
Father" ". In the same fashion, Basil considers the Holy Spirit to be a "light

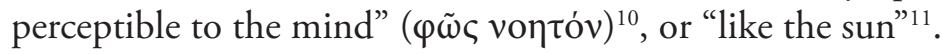

In Basil's mystical language, this imagery of light appears to serve a dual function. First, the author employs the common terms to describe the indescribable God Himself ${ }^{12}$, or at least some of His properties such as one-

Clarendoniano, 1905). For an overview of the theme in other Greek writers, see: Rudolf Bultmann, "Zur Geschichte der Lichtsymbolik im Altertum," Philologus: Zeitschrift für das klassische Altertum, 97 (1948). Bultmann (8) summarizes: "Im Griechischen wird das Licht zum Symbol für das Leben und für das, was das Leben erhält, oder für den, der als Retter des Lebens erscheint." Before Basil, the theme recurs in Eastern theologians such as Clement of Alexandria, see: Eric Osborn, Clement of Alexandria (Cambridge: Cambridge University Press, 2005), 208; Origen, F. Ledegang, Mysterium Ecclesiae: Images of the Church and its Members in Origen (Leuven: Uitgeverij Peeters, 2001), and Athanasius, Jaroslav Pelikan, The Light of the World: A Basic Image in Early Christian Thought (New York: Harper \& Brothers, 1962). After Basil, the imagery is employed by authors like Dionysius the Areopagite, see e.g.: coel. 1.1, 2; 2.5; 3.2; 13.3; PG 3, 120-21, 144, 165, 301, passim, Maximus Confessor, e.g. In de div. nom. 1, PG 4, 188; Myst. 1, PG 91, 665, Symeon the New Theologian, see: Karoliina Maria Schauman, "The Beauty of the Light of God in St Symeon the New Theologian," in The Beauty of God's Presence in the Fathers of the Church. The Proceedings of the Eighth International Patristic Conference, Maynooth, 2012, ed. Janet Elaine Rutherford (Dublin, Ireland: Four Courts Press Ltd, 2014), 257-66; Basil Krivocheine, In the Light of Christ: Saint Symeon the New Theologian. Life, Spirituality, Doctrine (Crestwood, New York: St Vladimir's Seminary Press, 1986), 223, 231, 236, 257-58, and Gregory Palamas, Norman Russell, Gregory Palamas and the Making of Palamism in the Modern Age (Oxford: Oxford University Press, 2019), 165-68.

${ }^{6}$ Hex. 1.2, SC 26, 96. Cf. 1.5, SC 26, 104; 2.5, SC 26, 162. Cf. Origen's (Comm. Io. 1.25,

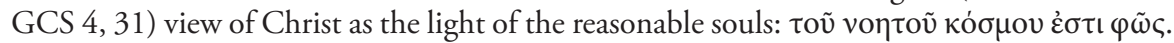
Later, Palamas offered a gloss to this description, maintaining that the light of grace transcends the intellect, and therefore cannot be called "noetic" in the proper sense, see Russell, Gregory Palamas, 201.

${ }^{7}$ Hex. 6.1, SC 26, 330. Prior to Basil, Christ is likened to the sun by Origen (Comm. Io. 1.25, GCS 4, 31). See also: Athanasius, inc. verbi 29, PG 25, 145.

${ }^{8}$ Ep. 52.2, PG 32, 393.

9 Spir. 8.19, SC 17, 312, 316. See also: Ep. 9.3, PG 32, 272; Eun. 2.16, SC 305. Cf.

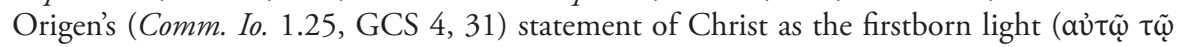

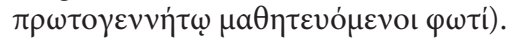

${ }^{10}$ Spir. 9.22, SC 17, 324.

${ }^{11}$ Ibidem, 9.23, SC 17, 328. See also: 18.46, SC 17, 410; 26.64, SC 17, 476.

${ }^{12}$ See e.g.: Eun. 1.7, 10, SC 299. For discussion on Basil's vindication of "common usage" of terms, see: Mark DelCogliano, Basil of Caesarea's Anti-Eunomian Theory of Names: Christian 
ness, simplicity and goodness. ${ }^{13}$ Basil admits that such words can offer only a "shadow of the truth" as to the magnificent nature of the Divine. ${ }^{14}$ As words describing the sun would fail to grasp all aspects of the brilliance of this celestial body, so also the images used in theological discourse can serve as little more than signs that lead one's mind toward a Divine referent whose nature is ultimately inexplicable. ${ }^{15}$ Thus, it is clearly not Basil's purpose to use the imagery of light to equate the Divine with a sensible physical phenomenon, or to attempt detailed explanations of His essence. ${ }^{16}$

Granted, in some cases the imagery of light lends itself well to depicting intra-Trinitarian relations. For Basil, the Son is the begotten light who has shone forth from the Father, the unbegotten light. ${ }^{17}$ In De Spiritu Sancto, however, one function of the metaphor of light seems to be to make the reader aware of the transcendence of $\mathrm{God}^{18}$. Simultaneously, as we will see, this metaphor implies the radical difference that lies between God and those who are ignorant of Him. In this manner, the narrative may also spur the readers to desire a closer participation with the Divine. This brings us to our next point.

Secondly, then, in employing the imagery of light, Basil's objective is to describe God's beneficent actions towards His creatures. While God, in His essence, is transcendent and, as such, incomprehensible for the human being, in Basil's view He is "made known through his activities." ${ }^{19}$ Certainly,

Theology and Late-Antique Philosophy in the Fourth Century Trinitarian Controversy (LeidenBoston: Brill, 2010), 158-63; Andrew Radde-Gallwitz, Basil of Caesarea, Gregory of Nyssa, and the Transformation of Divine Simplicity (Oxford-New York: Oxford University Press, 2009), 114-22.

${ }^{13}$ Cf. e.g. Eun. 2.29, SC 305. Here, it is important to note that unlike Eunomius, Basil contends that one name attributed to God - such as light - is not synonymous with His other names. See discussion in: DelCogliano, Basil of Caesarea's Anti-Eunomian Theory of Names, 140-44; Radde-Gallwitz, Basil of Caesarea, 158.

${ }^{14}$ Ep. 38.4, 5, 7, PG 32, 329, 333, 337. Cf. Gregory of Nazianzus (Orat. 31.3, 14, 26, 32-33, PG 36, 136, 149, 161, 164, 169, 172), who applies the metaphors of light and the sun to the Trinitarian Persons, and yet considers such "images" and "shadows" as "deceitful and very far short of the truth". See also Dionysius (coel. 2.3, PG 3, 140; cf. ibidem, 3.2, PG 3,165 ), who considers light to be merely an inadequate representation of the Deity.

${ }^{15}$ Cf. McConnell, Illumination, 3-4.

${ }^{16}$ What Radde-Gallwitz (Basil of Caesarea, 155) calls "Basil's agnosticism about the divine substance or essence", DelCogliano, Basil of Caesarea's Anti-Eunomian Theory of Names, 151, articulates thus: "Essences always remain incomprehensible for Basil."

${ }^{17}$ Eun. 2.25, SC 305; cf. 2.28, SC 305. See also Spir. 8.19, SC 17, 316; Ep. 38.7, PG 32, 337. For discussion on the intra-Trinitarian use of this imagery in Athanasius and other Greek fathers, see: Pelikan, The Light of the World, passim.

${ }^{18}$ See e.g.: Spir. 18.46, SC 17, 410.

${ }^{19}$ McConnell, Illumination, 1. 
participation in these activities is inconceivable apart from the presence of God Himself. However, time and again, the Cappadocian proclaims the light par excellence, God, who is, for the human intellect, the source of spiritual illumination. ${ }^{20}$ Basil's works are replete with descriptions of the divine activity ad extra, whereby the human being is received into God's presence, and her/ his understanding is illuminated and bestowed knowledge of the truth, i.e., of God Himself. ${ }^{21}$ Whereas in some of these passages the enlightening role is attributed to the Father ${ }^{22}$, in others the illumination is ascribed more specifically to the Father through the Creator Word, i.e., the Son. ${ }^{23}$ In De Spiritu Sancto, however, Basil emphasizes the role of the Holy Spirit as the revealer of the Son, in whom the Father is revealed. In this way, the Spirit acts as the supplier of divine illumination to human intelligence. ${ }^{24}$ Ultimately, the crux of the matter is this: The one and eternal God communicates His spiritual grace and the fullness of His divine presence to human beings ${ }^{25}$. In the presence of the light of the Spirit, they can see - i.e., know - the Light Himself.

However, there is one caveat. While Basil holds that the Holy Spirit is beyond the created order ${ }^{26}$, he also maintains that $\mathrm{He}$ is omnipresent ( $\pi \alpha v \tau a \chi 0 \tilde{v}$ ö $v$ ), offering the wholeness of His grace to everyone, like the

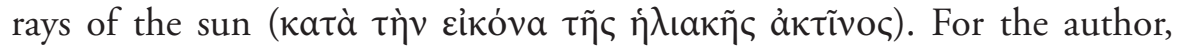
this means that the Spirit is present to everyone who is capable of receiving

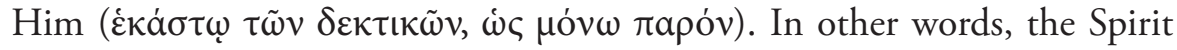
is enjoyed by those who partake of Him according to the capacity of their

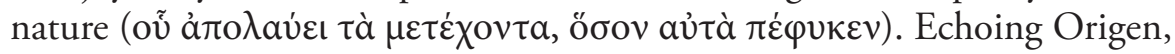
and reminding one of Plotinus, Basil maintains that the participation of

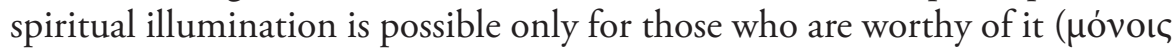

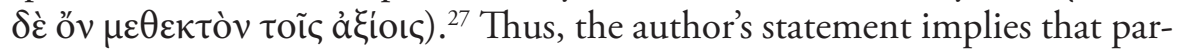

\footnotetext{
${ }^{20}$ Cf. the Dionysian interpretation of symbolism of light "for its higher meaning", see: Paul Rorem, The Dionysian Mystical Theology (Minneapolis: Fortress Press, 2015), 47.

${ }^{21}$ Again, this concept bears resemblance to Plato's doctrine of the sun deity as the cause of sight, see: Resp. VI 508b, e, Burnet, ed., Platonis Opera VI. In Dionysius (see e.g. coel. 7.3, PG 3, 209), too, spiritual illumination is equated with purification of ignorance, and the reception of divine knowledge.

${ }^{22}$ Hex. 2.8, SC 26, 184.

${ }^{23}$ Spir. 8.19, SC 17, 312. Cf. 8.18, SC 17, 308-9; 14.33, SC 17, 362s; Eun. 1.7, SC 299.

${ }^{24}$ Spir. 9.22, 23, SC 17, 324, 326, 328; 16.38, SC 17, 376, 382, 384; 18.46, 47, SC 17, 410, 412; 21.52, SC 17, 436; 26.61, SC 17, 466, 468; 26.64, SC 17, 476.

${ }^{25}$ Cf. Russell, Gregory Palamas, 176.

${ }^{26}$ Eun. 3.6, SC 305, 168.
}

${ }^{27}$ Spir. 9.22, SC 17, 324, 326. See also 18.46, SC 17, 410. While the idea of any direct connection between Basil and Neoplatonism has been contested, see: John M. Rist, "Basil's "Neoplatonism»: Its Background and Nature," in Basil of Caesarea: Christian, Humanist, Ascetic. Part One (Toronto-Ontario, Canada: Pontifical Institute of Mediaeval Studies, 1981), 
ticipation in divine light is not self-evident. This has much to do with what he says about darkness.

By his occasional engagement with the concept of darkness - the polar opposite of light - Basil does not refer to the utter absence of light. It could be proposed that for him such an absence would even be impossible, since in his rhetoric light is the image of God, the eternal source of being. Correspondingly, by the image of darkness, the author refers to the absence or minimal amount of divine light in the life of an individual, i.e. the state of his/her nonparticipation in this light. Following Origen, Basil uses words

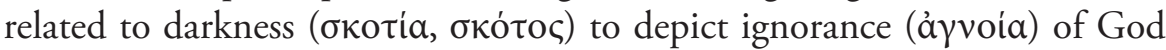
and His activity. ${ }^{28}$ In De Spiritu Sancto, he offers two explanations of the theme. In the first place, he likens absence of the Spirit to the withdrawal of light at night. Lack of visible light renders the faculty of the eyes inactive, resulting in a sort of blindness, or an inability to distinguish valuable objects from unworthy ones. In the same manner, beholding the mysteries of God is impossible without the revelation of the Spirit. ${ }^{29}$ Secondly, failing to train the mind (voṽc) to contemplation, and burying it in passions of the flesh, as it were in mud, make it impossible for such a "carnal person" to look up to the spiritual light of the truth. Just as a weak eye cannot receive sunlight, so

the Caesarean's statement in 9.22 is reminiscent of - if not phrased identically to - Plotinus' doctrine of the presence of the authentic existent for everything that is capable of receiving it, see. Enn. 6.4.3, Paul Henry and Hans-Rudolf Schwytzer (eds.), Plotini opera, tomus III (Oxford: Oxford University Press, 1983). Also, Torstein Theodor Tollefsen, Activity and Participation in Late Antique and Early Christian Thought (Oxford: Oxford University Press, 2012), 37, notes the similarity between the conceptions of Basil the Christian, and those of the Neoplatonists. For Origen's notion of spiritual worthiness, see e.g.: Hom. Luc. 3, GCS 9, 22; Comm. Io. 6.36, GCS 4, 145; princ. praef. 3, GCS 5, 9; 1.3.7, GCS 5, 60. Furthermore, Basil's use of the platonic concept of participation ( $\mu \varepsilon \theta \varepsilon \kappa \tau o$ v, $\mu \varepsilon \tau \varepsilon \dot{\varepsilon} \chi v)$ anticipates that of later authors like Dionysius (see e.g. div. nom. 4.1, PG 3, 693) and Gregory Palamas, cf. Russell, Gregory Palamas, 165-69; Tollefsen, Activity and Participation, 113-17, 188-92.

${ }^{28}$ Spir. 8.19, SC 17, 312; Hex. 6.2, SC 26, 334. On Origen's use of the image of darkness to depict ignorance, see: Ledegang, Mysterium Ecclesiae, 615-16. Before Origen, the image appears e.g. in Irenaeus, see: Adv. haer. 4.6.5; 4.39.4; 5.27.2; 5.28.1; SC 100, 152. The Irenaean text - in both the Greek and Latin versions - uses the image mainly for describing the present and future states of those who have separated themselves from the eternal light of God, without explicitly mentioning ignorance. Irenaeus does, however, liken the state of darkness to blindness - an image which appears in Basil as well, as we will see below. Cf. also Bultmann's ("Zur Geschichte," 13) description of the concepts of light and darkness in Greek authors: "der Dualismus von Licht und Dunkel wird zu dem von vocĩv und ä $\gamma$ voıa, von Erkenntnis, verstehendem Wissen, und Wahn."

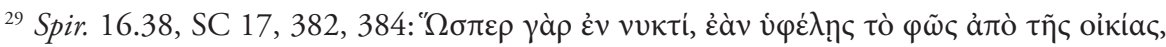

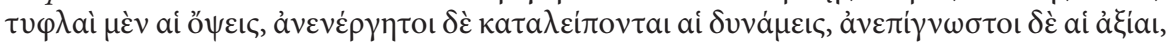

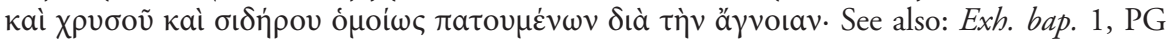
31,424 . 
also the carnally oriented person cannot receive the grace of the Spirit. ${ }^{30}$ In both cases, Basil's narrative illustrates the unfortunate end where one is left without spiritual illumination and grace, and - even in the very presence of this true light ${ }^{31}$ - in the darkness of his own individual mind. Basil describes this darkness as a power that keeps the ignorant under its dominion, ${ }^{32}$ and leads them to eternal condemnation. ${ }^{33}$

In summary, for Basil the imagery of light appears to be a toolkit of rhetorical devices from which he draws as he attempts to express his thoughts on mysteries that cannot be thoroughly articulated in human language. These rhetorical devices serve two functions. First, Basil employs light-related vocabulary to depict the Divinity, His transcendence and ineffable magnificence. Secondly, the imagery of illumination is used to describe God's beneficent actions ad extra. In Basil's view, the Holy Spirit supplies divine illumination to human intelligence, thereby bestowing us with knowledge of the Divine. All this occurs in and through the presence of the Spirit. Therefore, spiritual illumination is equated with participation in the divine light, i.e., in God Himself.

In this way, for Basil, the imagery of light is indicative of communion and participation - first, in the intra-Trinitarian sense, and secondly, insofar as human beings are received into relationship with and granted the knowledge of the Divine through His grace. In contrast, Basil uses the image of darkness to depict the ignorance of God, and the consequent nonparticipation, individualism, and infinite solitude.

\section{Church Membership}

After discussing the functions of light-related imagery, and before proceeding to the relationship of this imagery with Church membership, it is helpful to provide a brief outline of Basil's view on the nature of this membership itself. First, however, it bears noting that - as could be expected of late 4th century Christian literature - in Basil, neither ecclesiology nor the doctrine

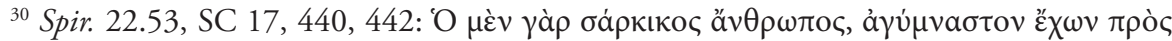

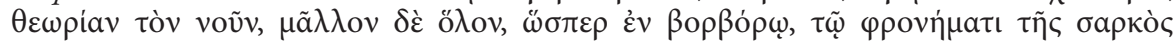

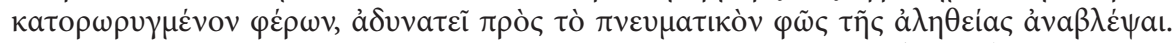

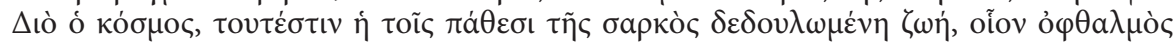

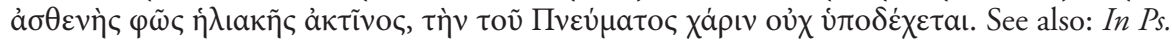

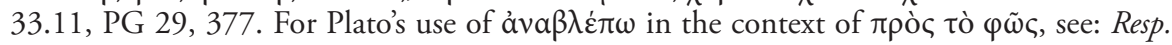
VII 515c, Burnet, ed., Platonis Opera VI.

${ }^{31}$ Cf. Hex. 8.7, SC 26, 464, 466.

32 Spir. 8.18, SC 17, 308.

${ }^{33}$ Ibidem, 11.27, SC 17, 340. Cf. Bultmann, "Zur Geschichte," 5: "Das ist das Bittere am Sterben, daß es der Abschied vom Licht ist.”
} 
of Church membership are systematically formulated. The lack of precise systematization of these themes may be partly due to the author's apophatic approach $^{34}$, but it is also likely due to the fact that in his day, a need for such formulations was yet to emerge. ${ }^{35}$ Nonetheless, the themes themselves - the Church and membership in it - are very much present in Basil. In order to discuss his view on the latter theme in a concise fashion, I have chosen to use the modern expression "Church membership" in this article.

For Basil, the Church is primarily a divine reality, based upon the fellowship of the Persons of the Trinity. Simultaneously, the Church is a fellowship of human beings, constituted by the Holy Spirit together with the Father and the Son. ${ }^{36}$ Through divine activity, humans are first received into fellowship with the Triune God. As a consequence, they enter into fellowship with other partakers of this mystical union, i.e., with other believers. This, fundamentally, is Church membership as the Caesarean understands it. In other words, Church membership may be summarily defined as corporate participation in divine life through the gracious activity of the Spirit.

Like other ecclesiastical writers of his era, Basil describes this participation and its effects by employing Biblical imagery of the Church and its members. In his ecclesiological gallery, among the most significant images are, e.g., the body of Christ, the people of God, the family, city, house of God, and the heavenly kingdom. In addition, nuptial and botanical imagery are frequently used in describing the relationship between God and the members of His Church. Up until now, as mentioned above, light and illumination have received surprisingly little attention as depictions of Church membership.

Obviously, an exhaustive documentation of the images of the Church, as well as a thorough inquiry into their relationship with Church membership are beyond of the scope of this study. Should such tasks be undertaken, one would be led to examine Basil's views on issues like the eucharist as a means of union, or spiritual healing as a means of restoring lapsed members to the healthy body that is the Church ${ }^{37}$. Furthermore, in addition to cover-

\footnotetext{
${ }^{34}$ See Druzhinina, The Ecclesiology, 59.

${ }^{35}$ Cf. Vladimir Smalij, "Ecclesiology: the Unfinished Project," in Sinappi, St. Petersburg and Siikaniemi: The 13th, 14th and 15th theological discussions between the Evangelical Lutheran Church of Finland and the Russian Orthodox Church, Documents of the Evangelical Lutheran Church of Finland 13, ed. Tomi Karttunen (Helsinki: Church Council, 2013), 332: "The Holy Fathers did not rely on theory, but on a self-evident, gifted experience of the Church. To a certain extent the broader musings on the different dimensions of the Church's existence emerged during the age of the heresies, when important aspects of the Church's identity (such as unity and apostolicity) were subject to doubt."

${ }^{36}$ Druzhinina, The Ecclesiology, 42. See also: 176.

${ }^{37}$ I have recently examined this issue elsewhere, see: Harri Huovinen, “Towards Participation in the Healthy Body: Spiritual Healing and Church Membership in Cyril of Jerusalem, Basil of Caesarea and John Chrysostom," in Homilies in Context, Studia patristica Fennica 9, eds.
} 
ing the spiritual aspects of Church membership, much could be stated about Basil's model of what nowadays would perhaps be regarded as sociological aspects of ecclesial life, such as mutual relations between the members of the Church, their individual functions, and deeds of charity towards other members ${ }^{38}$. However, since I will deal more extensively with the fruits of Church membership in connection with Basil's concept of participation in divine light below, these comments will suffice for our purposes.

In the next section, I will concentrate on the relationship of the topics examined thus far - the imagery of light and Church membership.

\section{The ecclesial nature of divine illumination}

\section{Christian Initiation as Illumination}

As McConnell rightly observed, "[i]n Basil's view, to be in the Holy Spirit is to be in the light of God where knowledge of God is possible." 39 For us, the crucial question is: Where exactly, according to Basil, is this possible, and how? The brief answer is as follows: This is in the Church, and in connection with its liturgical life. Indeed, it can be argued that in the Basilian understanding, divine illumination is more than individual knowledge of God in the Spirit. It is even more than individual participation in the divine life through the Spirit. For the Caesarean, divine illumination is an ecclesial mystery.

To begin with, the ecclesial nature of divine illumination is evident from the means whereby it is conferred. Following the tradition already evident in Justin Martyr ${ }^{40}$, Basil holds that Christian initiation is an essential means of spiritual illumination. The discussion of this theme in De Spiritu Sancto can be systematized in two phases.

Anni Maria Laato, Serafim Seppälä and Harri Huovinen (Helsinki: Suomen patristinen seura ry, 2020), 115-73.

${ }^{38}$ In connection with these themes, Basil draws heavily on the biological and familial imagery of the Church. This aspect of his theology is apparent especially in his ascetical works. Parenthetically, it may be suggested that in order to gain a thorough understanding of Basil's concept of Church membership, it would also be necessary to investigate his view of the relationship between ascetic communities and the Church. However, since this topic does not materially affect the present study, it is of little concern here. For a compact analysis of contrasting scholarly opinions on the issue, see: Huovinen, "Towards Participation," 118, n. 6.

${ }^{39}$ McConnell, Illumination, 1.

${ }^{40}$ Justin Martyr, 1 Apol. 61, PG 6, 421. On illumination vocabulary in the Greek Patristic writers after Justin and up to the time of Basil, see: Everett Ferguson, Baptism in the Early Church: History, Theology, and Liturgy in the First Five Centuries (Grand Rapids, MichiganCambridge, U.K.: William B. Eerdmans Publishing Company, 2009), 292, 311-12, 471, 474,572 . 
First, Basil discusses faith, by which the initiates are considered Christians. By "faith" the author refers to what could be taken as if an Augustinian expression is allowed - the fides quae, i.e., the content of Christian faith. For Basil, this is the faith which the candidates received $(\pi \rho \circ \sigma \delta \varepsilon \xi \dot{\alpha} \mu \varepsilon \theta \alpha)$ through baptismal instruction ( $\beta a \pi \tau i \sigma \mu \alpha \tau o \varsigma$

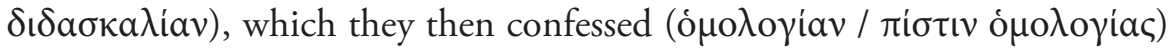
in the initiatory rite, and also personally believed (ö $\varepsilon \varepsilon \dot{\varepsilon} \pi$ He maintains that this tradition - i.e., of faith - has granted the knowledge of God to him personally, and thus introduced him into the light

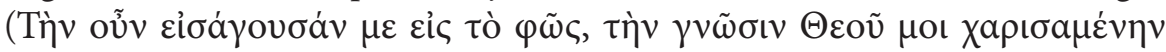
$\pi \alpha \rho a \dot{\delta} \sigma \sigma \iota v){ }^{42}$ Here, Basil's vocabulary reveals both communal and individual aspects of the initiation. On the one hand, he regards faith as a doctrinal matter which is bequeathed through the corporate activity of catechesis, and thereafter assented to, likewise in a corporate setting. On the other hand, the author can be understood as intimating at faith as a personal disposition. Even this aspect of faith, however, is connected with the ecclesial life of the initiates, for essentially it is the assent of the corporately confessed doctrine. Similarly, while the author does refer to his past introduction into light, even this personal illumination has been bestowed upon him through the ecclesial tradition of faith.

In connection with the above, it bears noting that in some passages Basil implies that illumination is granted through the use of Scripture ${ }^{43}-$ an apparent allusion to his own homiletical activity - or spiritual instruction ${ }^{44}$. In his day, most of this activity, if not all, is likely to have taken place in an ecclesial context. ${ }^{45}$

Secondly, more often than faith, Basil takes up the topic of baptism. He considers the initiates to be saved by baptismal regeneration. ${ }^{46}$ As to the

\footnotetext{
${ }^{41}$ Spir. 10.26, SC 17, 336, 338.

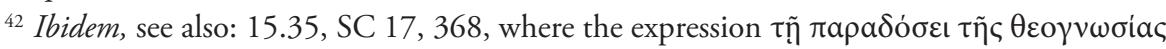
is used in the baptismal context.

${ }^{43}$ Hex. 1.2, SC 26, 96. This can be taken as an allusion to Basil's view of Scripture as inspired by and accompanied by the Spirit, see e.g.: Spir. 21.52, SC 17, 438; In Ps. 1.1, PG 29, 209; Ep. 283, PG 32, 1020. Scripture is discussed as a means of illumination also in Dionysius, myst. 1.1, PG 3, 997. See also: coel. 1.2, PG 3, 121.

${ }^{44}$ Hex. 6.2, SC 26, 334.

${ }^{45}$ McConnell (Illumination, 8) appears to agree: "The Holy Spirit inspires the Scriptures and governs their understanding in the church."

46 Spir. 10.26, SC 17, 336. When McConnell (Illumination, 69) states that "the illuminating work of the Spirit begins at baptism, regenerating the human being in his mind, instilling the possibility of knowledge of God", he is correct as far as the effect of baptism is concerned. His view of baptism as a beginning of illumination, however, appears to be partly inaccurate. Granted, Basil regards baptism as "the beginning of life," as we will see below.
} 
effects of this sacrament, the author's exposition - at least superficially - appears to introduce few novelties: On the one hand, the Caesarean adheres to the Pauline understanding that baptism signifies the putting off of carnal works ${ }^{47}$ and the death of our enmity towards $\operatorname{God}^{48}$. On the other hand, he maintains that in baptism, the Spirit is conjoined with the other Persons of the Trinity ${ }^{49}$. Therefore, the sacrament mediates spiritual grace ${ }^{50}$, the recipients of which are regenerated. ${ }^{51}$ That is to say, their souls are renewed

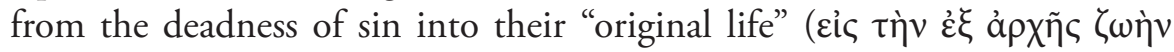

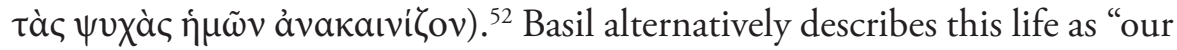
original glory as the image of God", into which "we are called" in baptism. ${ }^{53}$ The baptizands are translated from darkness to the light of the countenance of the Lord, which is signed upon them in the baptismal seal ${ }^{54}$. "In baptism," McConnell writes, "the mind is illumined for knowledge of God and the soul is empowered by the gift of the Holy Spirit." ${ }_{55}$ What is more, in the ecclesial rites of baptism, God bestows participation in the divine light and everything else that this image depicts - in goodness, life, and ultimately, in

To be exact, however, in Basil's view, the entire process of initiation - complete with the pre-baptismal tradition of faith - is illuminatory, as indicated above. Of course, if one were to refer to the initiatory process as a whole as "baptism" - a custom not unheard of, cf. Edwin Hamilton Gifford, "The Catechetical Lectures of S. Cyril, Archbishop of Jerusalem with a revised translation, introduction, notes, and indices by Edwin Hamilton Gifford, D.D.," in: NPNF2-07: Cyril of Jerusalem, Gregory Nazianzen, ed. Philip Schaff (Grand Rapids, MI: Christian Classics Ethereal Library), documentacatholicaomnia.eu/, accessed July 20, 2020, 22-23 - then one would perhaps be justified in stating that "the illuminating work of the Spirit begins at baptism." However, this does not appear to be the sense in which McConnell uses the word "baptism." While he does record Basil's views of pre-baptismal instruction (Illumination, 51-54), he clearly distinguishes this instruction from the baptismal ablution that follows it.

${ }^{47}$ Spir. 15.35, SC 17, 366.

${ }^{48}$ Ibidem, 14.31, SC 17, 358.

${ }^{49}$ Ibidem, 10.24, SC 17, 332, 334.

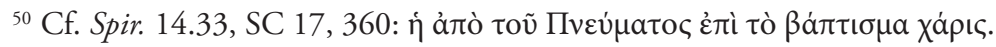

${ }^{51}$ Spir. 10.26, SC 17, 336; cf. 14.31, 32, SC 17, 356, 358; 15.35, 36, SC 17, 366, 370.

52 Ibidem, 15.35, SC 17, 368. This is another passage where the reader assumes a Platonic background, see Resp. VI 509b, Burnet, ed., Platonis Opera VI.

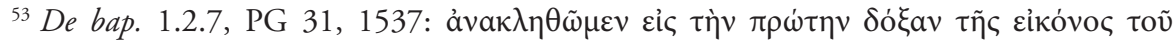
$\Theta \varepsilon$ oṽ. In my selection of sources for this study, I have followed the scholars who consider De baptismo to be an authentic work of Basil. For literature on the Basilian provenance of this text, see: Maxwell E. Johnson, The Rites of Christian Initiation: Their Evolution and Interpretation (Collegeville, Minnesota: Liturgical Press, 2007), 135; Ferguson, Baptism in the Early Church, 582.

${ }^{54}$ Exh. bap. 4, PG 31, 432.

${ }^{55}$ McConnell, Illumination, 32. 
Himself. Hence, the sacrament is called the "baptism of salvation" 56 , "baptism of redemption" 57 , and "the beginning of life" 58 .

Again, for our purposes it is essential to note that for Basil, participation in grace and divine light is more than an individual matter. Even if the author's occasional use of the first-person singular in describing the past event of his initiation might suggest otherwise, his exposition, and especially his chosen metaphors reveal the corporate nature of this salvation. For instance, the Caesarean equates baptism with the Pauline concept of adoption (vio $\theta \varepsilon \sigma i \alpha)$. Through "the grace of adoption as a son" conferred in the sacrament, he claims to have been "made a child of God." 59 The miraculous totality of this adoption causes Basil to wax lyrical:

Through the Holy Spirit comes our restoration to paradise, our ascension into the kingdom of heaven, our rising up to the adoption of sons, our liberty to call God our Father, our becoming partakers of the grace of Christ, our being called children of light, our sharing in eternal glory, and, in a word, our being brought into all fullness of blessing, both in this world and in the world to come, $[\ldots] .{ }^{60}$

\footnotetext{
${ }^{56}$ Spir. 10.24, SC 17, 332; cf. 14.31, SC 17, p. 358; 15.35, SC 17, 368.

${ }^{57}$ Ibidem, 24.55, SC 17, 450.

${ }^{58}$ Ibidem, 10.26, SC 17, 336; cf. 15.35, SC 17, 368.
}

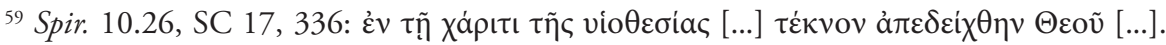

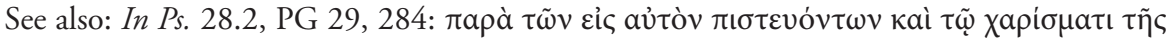

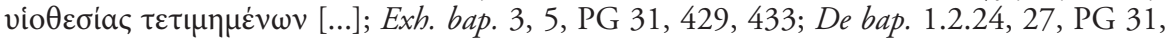
$1565,1572$.

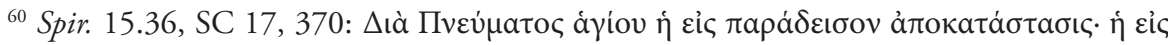

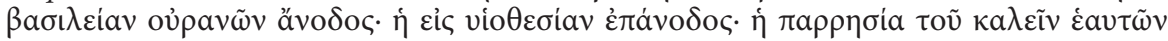

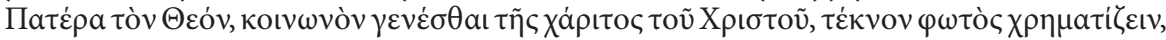

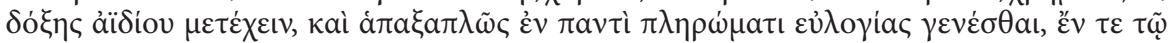

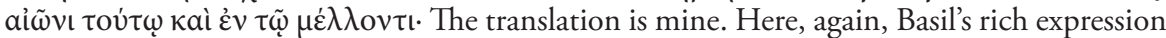
resembles that of Cyril of Jerusalem (Procatech. 16, Reischl, ed., Cyrilli Hierosolymarum ar-

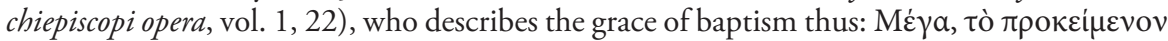

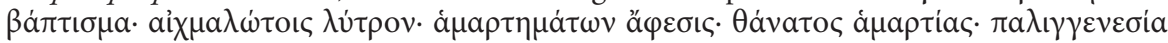

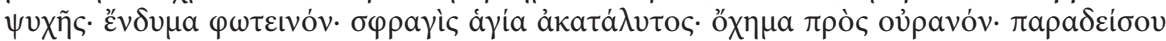

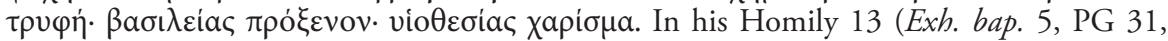
433), delivered approximately 20 years after Cyril's Procatechesis and four years prior to Spir., Basil repeats his Jerusalemite colleague's list of baptismal benefits almost verbatim: Bá $\pi \tau \iota \sigma \mu \alpha$

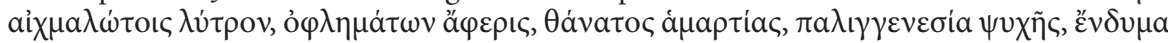

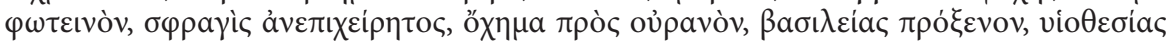

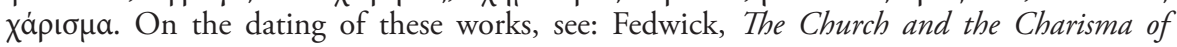
Leadership, 142, 149; Alexis James Doval, Cyril of Jerusalem, Mystagogue: The Authorship of Mystagogic Catecheses (Washington, D.C.: The Catholic University of America Press, 2001), 38, 44; Jan Willem Drijvers, Cyril of Jerusalem: Bishop and City (Leiden-Boston: Brill, 2004), 57-58; Donna R. Hawk-Reinhard, Christian Identity Formation according to Cyril of Jerusalem: Sacramental Theōsis as a Means of Constructing Relational Identity, Studia Patristica Supplement 8 (Louvain: Peeters Publishers, 2020), 53. 
Obviously, Basil's interpretation of the familial imagery of the Church cannot be discussed in detail here. It suffices to note that his terminology of adoption is directly related to the Scriptural title he attributes to baptized Christians, namely "the children of light." ${ }^{\prime 1}$ Clearly, the use of such a familial expression indicates the paternal bond which is created between the individual and God in baptism. At the same time, the expression presupposes the multiplicity of those who partake in the one divine reality, i.e., in God, who is light. Indeed, this terminology implies their mutual brotherhood in the family of God, i.e., the Church. ${ }^{62}$

Once again, the contrast between individual and communal can be seen in Basil's use of the Johannine image of the regeneration of water and Spirit. According to him, the Spirit is present in the baptismal water, injecting an enlivening power to the baptized, thus - as we saw above - renewing their souls from the deadness of sin into their original life, and enlightening their souls with His pure and heavenly light. ${ }^{63}$ It is of note that when Basil refers to "the body of sin," or to its burial in the water, he writes in general terms, avoiding personal pronouns. However, when he takes up the regenerative aspect of baptism, he explicitly refers to "our souls" and "our life" in the first-person plural. ${ }^{64}$ While the author's language is not completely consistent, the choice of words in this particular instance may indicate that in his concept, life in "the body of sin" is identified with the loss of one's true personality; whereas baptismal illumination incorporates one into a community of the enlightened, and reveals her/his personality as a living creature of God.

In another passage, this theme is explained further. As above, Basil likens the Spirit to the sun, and describes His illuminative effect on human beings. He also mentions those who have been purified from their shame to their natural beauty, and likens them to bright and transparent substances.

\footnotetext{
${ }^{61}$ See also: Spir. 11.27, SC 17, 340.

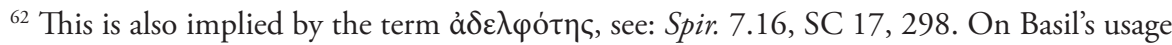
of this term in reference to the Christian community, see: Fedwick, The Church and the Charisma of Leadership, 23-24.

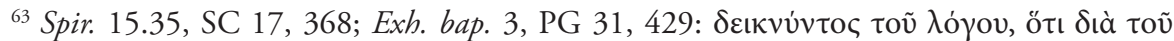

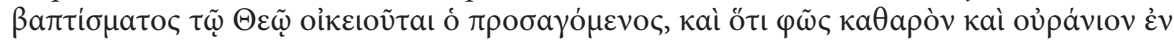

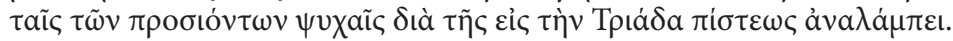

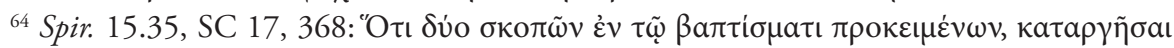

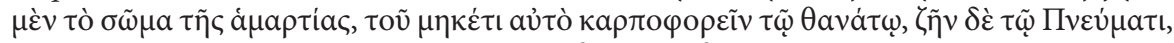

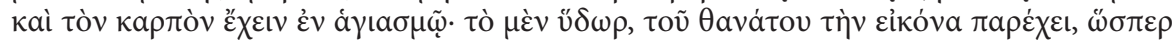

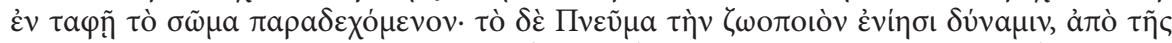

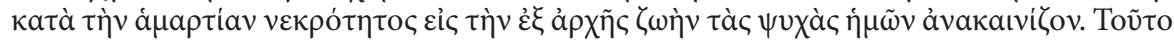

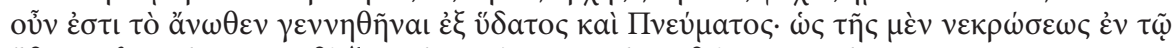

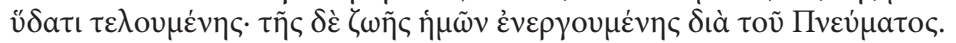


As the rays of the Spirit fall upon these pure persons, they become brilliant as well, being made partakers of the fellowship with the Spirit ( $\tau \tilde{\eta}$ $\pi \rho$ ò

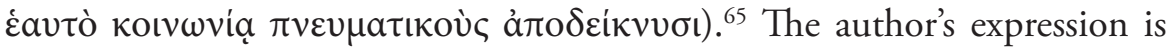
strongly indicative of an ecclesial setting where individual persons are made partakers of the one salvific reality, ultimately the fellowship with God Himself. ${ }^{66}$ Similarly, Basil uses concepts that can hardly be divorced from his understanding of baptism as a death to sin, and as the means of spiritual

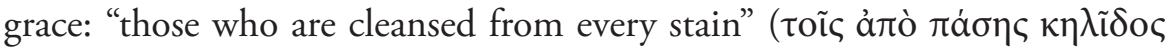

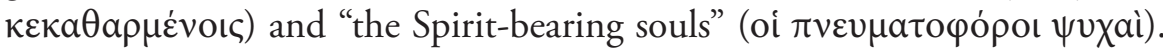
These concepts indicate that the author presupposes baptism as the means of the illumination of the Spirit as well as the union in the fellowship with Him.

In this way, Basil situates the mystical event of divine illumination in the ecclesial rites of initiation, first in the instruction of faith and corresponding confession, and secondly in baptism. Like Justin, the Caesarean identifies illumination with both aspects of the initiation or - as the matter should perhaps be interpreted - with the process of initiation as a whole ${ }^{67}$. Indeed, Basil contends that no one can be illuminated without being baptized ${ }^{68}$, i.e.,

${ }^{65}$ Ibidem, 9.23, SC 17, 328.

${ }^{66}$ Panagiotis Christou, "Die Sorge des Basilius um die Koinonia der Kirche," in Basilius: Heiliger der Einen Kirche (München: Verlagsgesellschaft Gerhard Kaffke, 1981), 57-58, appears to agree: "Für den Erzbischof von Cäsarea ist «Koinonia» kein leeres Wort, sondern ein wirklicher Zustand des Kirchenorganismus als Körper Christi und Sitz des Heiligen Geistes; sie ist ein Bestandteil der Kirche."

${ }^{67}$ Also Justin's (1 Apol. 61, PG 6, 420-21) view on Christian initiation can be roughly divided into two stages: 1) instruction, probably a confession of faith, prayer, and penitential fasting; 2) baptism in the name of the Triune God. McConnell (Illumination, 49-50) rightly indicates the similarity between the baptismal views of Justin and Basil, but he fails to mention explicitly the illuminative role, attested to by both authors, of the two aspects of the initiatory process. In his gargantuan study Baptism in the Early Church (241), Ferguson offers a brief but apt commentary on the instructional side of Justin's enlightenment. Unexpectedly, however, he leaves out any explanation of the enlightening role of the actual rite of baptism, mentioning (474) it only in the context of the Jerusalemite rite of baptism recorded in Cyril.

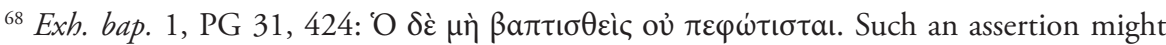
appear to contradict Basil's abovementioned view (Spir. 9.22, SC 17, 324, 326) that the Holy Spirit is omnipresent, offering the wholeness of His grace to everyone. Indeed, the omnipresence of the Spirit might be interpreted as indicating that spiritual illumination is accessible even without baptism. Furthermore, Basil (Hex. 1.5, SC 26, 106; 1.6, SC 26, 110) does consider the entire cosmos as a school where the human souls, based upon their perception of sensible things, might see the invisible and know God. The purpose of this statement, however, is not to belittle the importance of the ecclesial rites of initiation as means of illumination. Rather, the Caesarean aims to emphasize that the sensible world is not devised randomly or in vain, but that as God's creation, it is good, and serves an important purpose in the spiritual edification of rational souls. In fact, Basil is hesitant as regards human ability to know God apart from the illumination of the Spirit, see discussion in: McConnell, Illumination, 71, 125-40. Thus, he adheres to Origen's (princ. 4.2.4, GCS 
without partaking in the fulfilment of the initiation. ${ }^{69}$ Through this perfective baptismal process, the individual is received into communion with $\operatorname{God}^{70}$. That is to say, the baptizand is removed from the realm of ignorance, and, with his/her personal darkness being filled with the inexplicable luminosity of divine light, s/he is made one with the source of this light Himself.

Further, this initiatory illumination connects each individual with the community of the illumined, i.e., the Church. In this sense, one can say that in Basil's thinking, "we are saved not as individuals, but as members of God's family." ${ }^{11}$ Of course, it should be pointed out that the illumination, knowledge of God, and salvation pertain to each initiate as an individual as well. Even then, not only the rites whereby these gifts are conferred, but also the reality with which they connect each person is wholly ecclesial. Both of these aspects of Church membership - the individual and the communal - are "inextricably intertwined"72, and clearly illustrated in a passage where Basil quotes the Pauline statement (1 Cor. 12.13) on incorporation into the Body of Christ: "And as parts in the whole so are we individually in the Spirit, because we all were baptized in one body into one spirit."73

\section{The Partakers of Divine Light as Community}

As shown above, the illuminating grace of the Spirit is bestowed upon individual persons in an ecclesio-sacramental context. As we have also seen, bap-

5, 313-14; cf. 1.3.7, GCS 5, 58-60) view that the Holy Spirit works specifically within the Church, teaching human souls on their way to heaven. In Basil's mind, baptism - which he regards as an inseparable part of the illuminatory process - obviously belongs to this ecclesial context. On the Church and the world as realms of the Spirit in Origen and Basil, see: McConnell, Illumination, 101-3.

${ }^{69}$ Cf. Spir. 12.28, SC 17, 346, where Basil holds that through baptism, saving faith is perfected.

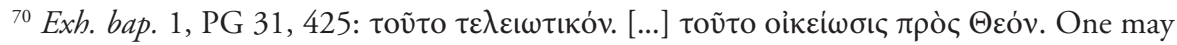
argue that in this context, oikei $\omega \sigma \iota \varsigma$ could also be translated as "kinship". Kenrick's translation of the passage is bolder: "this [baptism] unites with God". To highlight both of these aspects of the baptismal relationship with God, I have chosen to use "communion" (see:

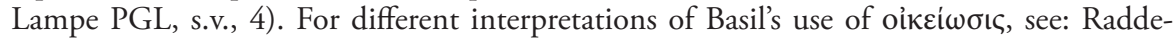
Gallwitz, Basil of Caesarea, 127-28.

${ }^{71}$ Druzhinina, The Ecclesiology, 76.

${ }^{72}$ Olavi Merras, "The Church as a Worshipping Community: An Orthodox Viewpoint," in The Finnish Lutheran-Orthodox Dialogue: Conversations in 1991 and 1993, Documents of the Evangelical Lutheran Church of Finland 7 (Helsinki: Church Council, 1995), 16. In Merras's words: "The two viewpoints of Christianity - personality and communality - are inextricably intertwined."

${ }^{73}$ Spir. 26.61, SC 17, 470. Translated by Blomfield Jackson, in NPNF2-07, eds. Philip Schaff and Henry Wace (Buffalo, NY: Christian Literature Publishing Co., 1895), newadvent.org/ fathers/3203/, accessed July 20, 2020. 
tismal illumination connects them with the Divine and the ecclesial reality of the community of His believers. But Basil emphasizes the nature of this divine union even further. Alluding to Col. 1.12-13, he explains that "we", i.e., Christians, "have been lead on to the Father through Him," i.e., Christ, "being translated from the power of darkness to the lot of the inheritance of the saints in light." ${ }^{74}$ Here, the Caesarean implies that this communion is two-dimensional: On the one hand, it is communion with the Father, realized through Christ. That is to say, it is participation in the luminous life of God, and the reception of His divine gifts. On the other hand, this participation is corporate in nature, since it pertains to multiple persons, i.e., the saints - or, as they are called in another instance, disciples of the Lord ${ }^{75}$. However, this participation connotes more than several individuals being simultaneously unified with God. Being made a partaker of the one divine sanctity - vertically, so to speak - unifies each individual - horizontally with the other partakers as well. As we have seen, this holiness and participation is effected by the Spirit, whom Basil regards as light. As partakers of the illumination of the Spirit, the holy ones have been set free from the state of darkness and the corresponding blindness, and made visible, as it were, in their "original life," or "original glory as the image of God"76. Thus, illumined by the one divine light, they are also connected with each other by it. This unifying nature of divine light - already implied in Plato ${ }^{77}$, and later articulated more precisely in a Christian context in the Corpus Areopagiticum ${ }^{78}$ - has been well explicated in biblical terms by Minear: "When this light shines in men's hearts it communicates not only a knowledge of God's glory but also fellowship in the light as a common inheritance."79

Further, the subsequent work of the Spirit is granted to the baptized in the context of the ecclesial community. This is evident in the way Basil appears to situate the enlightening activity of the Spirit in a liturgical setting. Describing the process whereby the vision of God is attained, the Caesarean writes:

\footnotetext{
${ }^{74}$ Ibidem, 8.18, SC 17, 308, 310. In this and similar cases, I have retained the word "saints," used in the Jackson translation of the Schaff and Wace edition. I have done so for the sake of brevity, not to imply an official act of canonization of saints which, of course, was yet to be established in Basil's time.

75 Ibidem, 22.53, SC 17, 442.

${ }^{76}$ See n. 52 and 53 above.

77 Plato, Resp. VI 508a, Burnet, ed., Platonis Opera VI.

${ }^{78}$ E.g. div. nom. 5.8, PG 3, 824; coel. 1.2, PG 3, 121. For discussion on the role of light in Dionysius' doctrine of participation, see: Tollefsen, Activity and Participation, 115.

${ }^{79}$ Paul S. Minear, Images of the Church in the New Testament (Louisville, Kentucky: Westminster John Knox Press, 2004), 128.
} 
When, by means of the power that enlightens us, we look fixedly on the beauty of the image of the invisible God, and through the image are led up to the supreme beauty of the sight of the archetype, then the Spirit of knowledge itself is present inseparably, in Himself bestowing on those that love the vision of the truth the power of beholding the Image, not making the exhibition from without, but in Himself leading on to the full knowledge. As no man knows the Father save the Son, so no man can say that Jesus is the Lord but by the Holy Ghost. [1 Cor. 12.3] For it is not said through the Spirit, but in the Spirit. And God is spirit, and those who worship him must worship him in spirit and truth, [Jn 4.24] as it is written in your light shall we see light [Ps. 35.10 (36.9)], namely by the illumination of the Spirit, the true light which lights every man that comes into the world. [Jn 1.9] Therefore, in himself he shows the glory of the Only-Begotten, and upon true worshipers [Jn 4.23] he in himself presents the knowledge of God. ${ }^{80}$

From this passage, three important observations can be made. First, as was the case in some passages analyzed above, here too the author's language implies a corporate setting. It seems to be no coincidence that Basil writes in the first-person plural, as if to emphasize his role as a representative of the community of baptized believers. It is the Christian congregation whose progress in spiritual illumination he is concerned about. Secondly, that his words are to be taken as a reference to baptized believers is apparent from the fact that he assumes "us" - i.e., himself and his readers - to have access to the enlightening power of the Spirit which, as indicated above, is conferred in the initiation. Basil can be read as referring to the synaxis of the baptized, where they partake of the Holy Spirit, and are thus led to a common theoria and knowledge of the Trinity. This view appears to be confirmed by the third observation: Alluding to the Johannine theme of "true worshipers" who worship "in spirit and truth" (Jn 4.23-24), Basil writes that "to the true worshipers He [the Spirit] in Himself presents the knowledge of God." Such an assertion can hardly be dissociated from the liturgical context of ecclesial life. ${ }^{81}$

\footnotetext{
${ }^{80}$ Spir. 18.47, SC 17, 412. Here, I have made some revisions to the Jackson translation. The Scriptural quotes are from the ESV, except for the Ps. 35.10 and Jn 1.9 passages, where Basil's text suggests a different rendering.

${ }^{81}$ Cf. Jaroslav Pelikan, “The «Spiritual Sense» of Scripture: The Exegetical Basis for St. Basil's Doctrine of the Holy Spirit," in Basil of Caesarea: Christian, Humanist, Ascetic. A Sixteen-Hundredth Anniversary Symposium. Part One (Toronto-Ontario: Pontifical Institute of Mediaeval Studies, 1981), 339-40, passim. In his article, Pelikan interprets much of Spir. as having a liturgical context, even where unmentioned.
} 
Similarly, as Basil discusses the spiritual progress that occurs "through the works of righteousness and the illumination of knowledge," he implicitly connects this progress with Christian life within the Church. For the author,

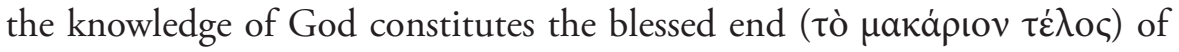
this spiritual progress. It is this knowledge that the Lord grants to those who

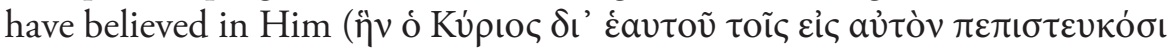
$\chi \alpha \rho i \zeta \varepsilon \tau \alpha)$ ) ${ }^{82}$ In this way, Basil reveals his presupposition that the recipients of this knowledge of God are the believers, i.e., those who have become members of the Church through the rites of Christian initiation. ${ }^{83}$

\section{The Outward Expressions of Life in Light}

While participation in divine light is conferred through an outward rite of initiation, it is essentially a spiritual matter that pertains to the life of the individual as well as the life of the Christian community as a whole. But the consequences of this participation are more than internal: Life in the divine light is manifested in perceivable ways. Basil's account of the outward expressions of this life can be divided into two categories.

One of these expressions is worship. Basil suggests that as "our intelligence" has been brought into the spiritual light, its activity can be described as "the worship in the Spirit." ${ }^{84}$ From the context, it seems clear that this allusion to John 4.24 is wholly ecclesial. To begin with, the author refers to multiple individuals who have been made worshipers by virtue of their participation in the divine life of the Spirit. The ecclesial nature of the statement is evident also from the manner in which the writer goes on to identify life in the Spirit with life in the Church. "For if you are outside of Him [the Holy Spirit], you will not [be able to] worship at all." ${ }^{85}$ Here, Basil employs the word $\tilde{\varepsilon} \xi \omega$ (outside) which, in both the NT and Patristic writers, is commonly used in reference to those outside the community of believers. ${ }^{86}$ In the present passage, the meaning appears to be the same. This statement could

\footnotetext{
${ }^{82}$ Spir. 8.18, SC 17, 310.

${ }^{83}$ For earlier examples of the use of $\pi \iota \sigma \tau$ ó $\varsigma / \pi \iota \sigma \tau o$ in reference to baptismal candidates and baptized Christians, see e.g.: Cyril of Jerusalem, Procatech. 2, Reischl, ed., Cyrilli Hierosolymarum archiepiscopi opera, vol. 1, 4; Catech. 1.4, ibidem, 32.

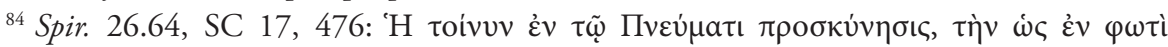

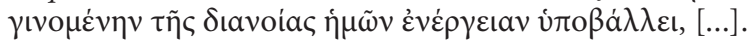

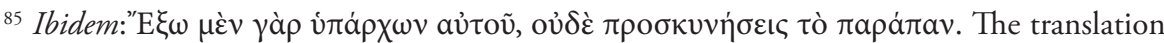
is mine.

${ }^{86}$ See e.g.: 1 Cor. 5.12; John Chrysostom, In Matt. hom. 6.2, PG 57, 65; Gregory of Nyssa, Eun. 12, PG 45, 1101. For discussion on problems related to a simplistic view of the "inside" and "outside" in later Patristic theology, see: Serafim Seppälä, "Anathematized Church Fathers: a Gateway to Ecumenism?," Review of Ecumenical Studies 11, no. 1 (April 2019): 25.
} 
be interpreted thus: Since the illuminating activity of the Spirit is conferred in the Church, remaining outside of the Church would mean remaining "outside of Him." Without the illumination of the Spirit, however, there would be no ecclesial unity in Divine participation, nor would there be worship, for both the unity and the worship are affected by the Spirit. While Basil does agree with the fourth Gospel in that spiritual worship cannot be limited spatially ${ }^{87}$, he still maintains that one can be either "outside" of the realm of the Spirit, or "in Him" ( $\dot{\varepsilon} v$ a $\dot{v} \tau \tilde{\varphi})^{88}$. The latter option would be synonymous with participation in the spiritual light that is conferred - as above - in the ecclesial rite of adoption, i.e., baptism. Without the Spirit of this adoption, as Basil maintains elsewhere, true worship is impossible. ${ }^{89}$ Therefore, in his view, true spiritual worship can only occur in the context of the Church and its spiritual membership. Stated in more positive terms, the Holy Spirit not only gathers individual Christians together, but also molds them into one worshiping community. ${ }^{90}$

Another expression of life in the divine light has to do with the witness of the Church. As partakers of the light of the Spirit, individual Christians act as intermediaries of this light. Basil portrays this clearly in his homily on Ps. 28:

He who is able himself to contemplate each individual creature with clear and unconfused thoughts and, after having contemplated them himself, is able to present to others also the facts concerning the goodness of God and His just judgment, he is the one who brings glory and honor to the Lord and who lives a life in harmony with this contemplation. For, the light of such a man shines before men [cf. Mt. 5.16], since by word and work and through manly deeds of every kind the Father in heaven is glorified. ${ }^{91}$

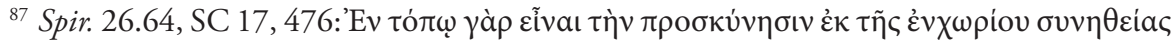
$\eta \dot{\pi} \pi \alpha \tau \mu \varepsilon \dot{v} \eta v$ ó Kúpı

${ }^{88}$ Ibidem.

${ }^{89}$ Ibidem, 11.27, SC 17, 342.

${ }^{90}$ In Spir. 29.73 (SC 17, 508, 510), the ecclesio-liturgical setting of worship is revealed even more explicitly. Basil mentions an ancient liturgical practice where words of thanksgiving and worship to the Trinity are offered in the service of the Lucenare, or the lighting of the lamps. This is one more proof that in Spir., worship is a communal event that is connected with the tradition of the Church. On the practice of the Lucenare in late 4th century Jerusalem, see: Egeria (It. Eger. 24.4, SC 296): "Hora autem decima, quod appellant hic lycinicon, nam nos dicimus lucernare, [...]." See also: Drijvers, Cyril of Jerusalem, 78, 80.

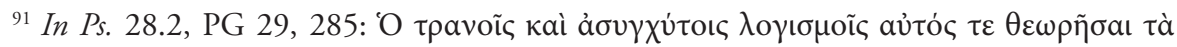

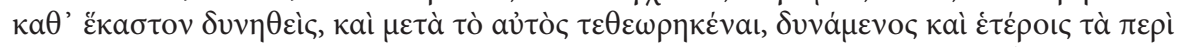

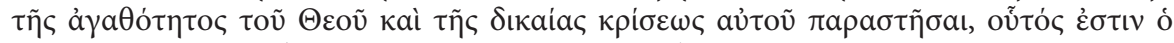

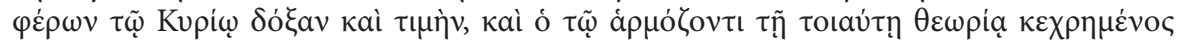


Here the homilist maintains that participation in divine light not only grants Christians a clear perception of the works of God, but also enables them to share this light of divine understanding with others.

In his letter to Palladius, Basil also mentions how a Christian shines. Here, however, he appears to emphasize the baptismal origin of this light that shines in the Christian, Palladius. According to the epistoler, the Lord has made Palladius His own, alienated him from sin, and opened the doors of heaven for him - apparently in baptism. Referring to these divine works

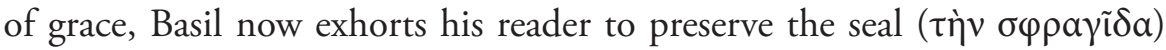
inviolate, so that he might stand before the Lord, shining in the splendor of the saints. This holiness and light he identifies with the baptismal garment. ${ }^{92}$

A similar theme is presented in De Spiritu Sancto where, in praising the miraculous works of Gregory of Neocaesarea, Basil likens this bishop to a lantern or beacon that shone all over in the Church of God (oĩov tiva

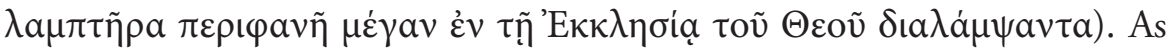
a participant of the same Spirit as the apostles and prophets, Gregory had the co-operation of the Spirit with him. Thus, everything he accomplished through grace, by both word and deed, indicated that the heavenly power

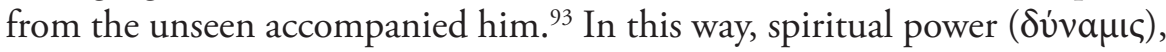
though essentially invisible, became perceptible in the life of the bishop.

The theme of beacons also recurs in another passage. Writing about the lanterns of the world, "whom God has placed to illumine the souls of the people," Basil laments the Arian schism that has led to the expulsion of these luminaries from their homes. As a result, a darkness has settled on the churches. ${ }^{94}$ If we believe Basil is referring to congregational leaders ${ }^{95}$, he can be taken as implying that their teaching, works, or both, are the source of light whose illumination brings unity to the whole congregation. In their absence, therefore, the churches are left without this light, and therefore also without unity. Indeed, the paragraph is replete with descriptions of the

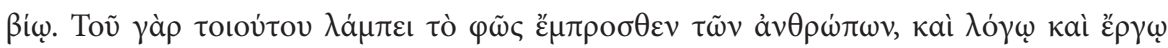

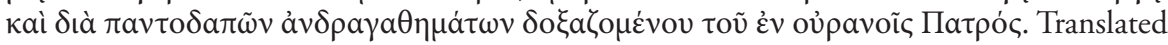
by Agnes Clare Way, in: Saint Basil: Exegetic Homilies, The Fathers of the Church, A New Translation, vol. 46, eds. Hermigild Dressler, Robert P. Russell, Thomas P. Halton, et. al. (Washington, D.C.: The Catholic University of America Press, 1963), 196.

${ }^{92}$ Ep. 292, PG 32, 1033. On the sphragis as a baptismal symbol in the Greek fathers, see: Jean Daniélou, Bible et liturgie: La théologie biblique des Sacrements et des fêtes d'après les Pères de l'Église (Paris: Les Éditions du Cerf 1958), 76-96.

93 Spir. 29.74, SC 17, 512.

${ }^{94}$ Ibidem, 30.77, SC 17, 524.

${ }^{95}$ Cf. coel. 13.4, PG 3, 305, where the author mentions servants and priests as agents of

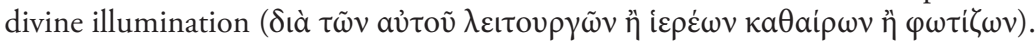


regrettable effects of schism, whereby the unity of the Church is shattered and replaced with individualism.

It is true, then, that in Basil's mind, "[o]nce a believer is cleansed and indwelled by the Spirit, he becomes a source of spiritual light for others in the community." 96 However, the author's perspective to the matter is even broader than this. In some cases, the Caesarean appears to ascribe the illuminative role to the whole congregation. In his letter to the bishop

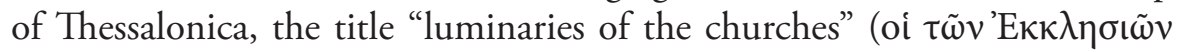
$\varphi \omega \sigma \tau \tilde{\eta} \rho \varepsilon \varsigma)$ is given to the local Christians together. While few in number, they shine in the world's darkness as a conjunction of stars on a moonless night. The author appears to identify this brilliancy with the character of discipleship of Christ, which is manifested as love and virtue. ${ }^{97}$ Even then, this luminosity is not an inherent quality in believers. Rather, as Basil emphasizes in his homily on the Hexaemeron, the saints have become luminous by participation in the true light. Hence, they have also become luminaries

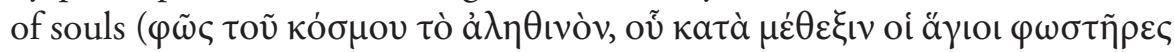

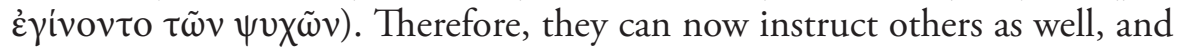
draw them out of the darkness of ignorance. ${ }^{98}$

The same theme appears in De Spiritu Sancto as well: Having become brilliant in participation in the fellowship with the Spirit, the members of the spiritual community send forth grace to others. That is to say, via the action of the Church, others can also be made partakers of the spiritual grace. Thus they, too, can gain a place in the celestial chorus, and a dwelling in

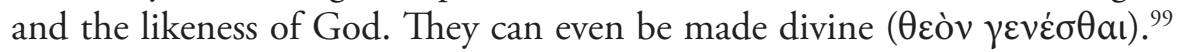
For Basil, the light of the Spirit and grace being distributed in this way is a

\footnotetext{
${ }^{96}$ Druzhinina, The Ecclesiology, 40.

${ }^{97}$ Ep. 154, PG 32, 609, 612. Cf. Ep. 28.1 (PG 32, 305), where Basil describes the Church with similar light-related vocabulary. Before Basil, the image of stars had been frequently employed by Origen (see e.g.: Comm. Io. 1.25, GCS 4, 31; orat. 23.4, GCS 2, 352) in reference to Christians.

${ }^{98}$ Hex. 6.2, SC 26, 334. In this passage, Basil's expression appears to be reminiscent of the lunar imagery of Origen (see. e.g.: Comm. Io. 1.25, GCS 4, 31), according to which the Church reflects the divine light, as the moon would reflect the rays of the sun. The reflecting role of the partakers of the divine splendor appears later in Dionysius, coel. 3.2, PG 3, 165. Cf. ibidem, 3.3; 15.4; PG 3, 165, 168, 333. On the Hellenistic backgrounds of early Christian lunar theology, see discussion in: Hugo Rahner, Symbole der Kirche: Die Ekklesiologie der Väter (Salzburg: Otto Müller Verlag, 1964), 92, 98-104, 141-49, 163-67. On celestial imagery in Origen's ecclesiology, see: Ledegang, Mysterium Ecclesiae, 614-15, 619-24, 627-34; 637-38; Rahner, Symbole der Kirche, 104-14.

${ }^{99}$ Spir. 9.23, SC 17, 328. At the time of Basil's writing, the Christian terminology of theosis was yet to be standardized. Here, the author appears to be echoing Athanasius' statement, in which the Alexandrian bases the concept of "being made god" on participation in the incar-

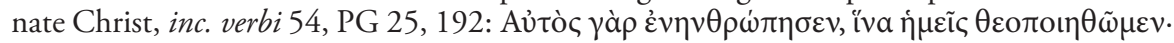


worldwide mission for the Church. This is also highlighted in his letters. For instance, referring to the pious reputation of the Beraeans, Basil asserts that the Lord Himself puts them - his worshipers - like a lamp on a lampstand, and displays the brightness of their splendor like the rays of the sun. $\mathrm{He}$ makes them shine throughout the whole world. ${ }^{100}$ Here he appears to refer to the whole Church in Beraea. This can be conjectured from the way the epistoler applies the Matthaean image of the lamp (Mt. 5.15) to the local Christians as a group, and probably also from his references to ecclesial acts such as confession of Christ and worship.

From the foregoing it can be inferred that for Basil, the Church, by virtue of its participation in "the true light of the world" 101 , is also the light of the world (cf. Mt. 5.14-16), and the lumen gentium, the light of the nations ${ }^{102}$ par excellence - or at least the light of those with whom its spiritually illumined and Spirit-bearing members come into contact. Even though non of the members of the Church are intrinsically luminous, when the world is in its darkness, the community of these holy people represents divine light itself. Pelikan aptly notes: "What radiated from the church to illumine the world was, in this ultimate sense, nothing less than the uncreated light that was God." 103

In sum, Basil's description of the expressions or fruits of life in divine light is not unlike that offered by Minear in his study of the image of light in the NT:

On the one hand, all these fruits enhance the inner cohesion of the community, [...]. On the other hand, these fruits qualify the church to live as a city on a hilltop (Mt. 5.14-16), to shine in the darkness, and to transform it. ${ }^{104}$

See also: Spir. 1.2, SC 17, 252. For further discussion, see: Norman Russell, The Doctrine of Deification in the Greek Patristic Tradition (Oxford: Oxford University Press, 2009).

${ }^{100}$ Ep. 221, PG 32, 816-17.

${ }^{101}$ Hex. 6.2, SC 26, 334. See also De bap. 1.2.11, PG 31, 1544.

${ }^{102}$ Curiously, while Lumen gentium, the Vatican II constitution on the Church, does mention the Church's participation in divine light, and its consequent task as a bearer of this light to the world, the document lacks a thorough inquiry into the Scriptural image of light in describing "the mystery of the church." See vatican.va/archive/hist_councils/ii_vatican_council/, accessed April 20, 2020. This minimalistic approach appears to be followed by notable post conciliar studies on Roman Catholic ecclesiology. Some offer passing references to the imagery of light (see e.g.: Hans Küng, The Church, trans. Ray and Rosaleen Ockenden [London: Burns \& Oates Limited, 1969], 64, 100-1, 326, 328, 375, 387, 481, 488), but others are silent on the subject (see e.g.: Avery Dulles, Models of the Church [New York: Image Books, 2002]; idem, Church Membership as a Catholic and Ecumenical Problem [Milwaukee, Wisconsin: Marquette University Press, 1981]).

${ }^{103}$ Pelikan, The Light of the World, 109.

${ }^{104}$ Minear, Images of the Church, 129. 


\section{Spiritual illumination: an ecumenical perspective}

For many modern readers, the late 4th century ideas presented above may amount to little more than a remnant of a bygone era. I argue, however, that the Basilian connection between participation in the divine light and Church membership bears deep ecumenical significance for today's churches. That said, I realize that engaging with the ecumenical implications of an ecclesiological theme from a classic post-Nicaean text may be considered an audacious task - especially if attempted in one section of a single research article. Keeping this in mind, I will limit myself to show one door which as it appears to me - still remains fully opened between two ecclesiologies: that of Basil and his followers on the one hand, and that of the 16th century Lutheran reformation and the supporters of its doctrinal positions on the other.

As is widely known, Martin Luther's expositions of the third article of the Apostles' Creed have had a central role in the ecclesiological self-understanding of Lutheran theologians. ${ }^{105}$ In the shorter exposition recorded in the reformer's Kleiner Katechismus, one of the chief roles of the Holy Spirit is said to be illumination. ${ }^{106}$ Luther's description of this activity is terse, but reminiscent of Basil's exposition of the same:

I believe that [...] the Holy Spirit has called me by the Gospel, enlightened me with His gifts, sanctified and kept me in the true faith. In the same way He calls, gathers, enlightens, and sanctifies the whole Christian church on earth, and keeps it with Jesus Christ in the one true faith. ${ }^{107}$

\footnotetext{
${ }^{105}$ In the Kleiner Katechismus, this ecclesiological dimension is only implied, and therefore has escaped the notice of many commentators. In the corresponding exposition offered in the Großer Katechismus, however, the ecclesiological nature of Luther's interpretation is apparent: The reformer repeatedly explicates the connection between his theology of the Spirit and the essence and role of the Church, see: Cat. maj. II 37, 41, passim, Die Bekenntnisschriften der evangelisch-lutherischen Kirche. Herausgegeben im Gedenkjahr der Augsburgischen Konfession 1930, Band 2 (Berlin: Evangelische Verlagsanstalt GmbH, 1978), 654-55. This connection is apparent also in later Lutheran commentators, see e.g.: Albrecht Peters, Kommentar zu Luthers Katechismen: Band 2. Der Glaube: Das Apostolikum (Göttingen: Vandenhoeck \& Ruprecht, 1991), 212 ff.; Edmund Schlink, Theology of the Lutheran Confessions, trans. Paul F. Koehneke and Herbert J.A. Bouman (Saint Louis: Concordia Publishing House, 1961), 199-201, 203.

${ }^{106}$ Cat. min. II 6, Die Bekenntnisschriften, Band 1, 511-2. In the text, the activity of the Holy Spirit is described with eight verbs. Four of these are repeated, resulting in a total number of 12 instances of the work of the Spirit. The verb mentioned in the second and seventh positions is "erleuchten", or illuminare in the equally normative Latin version of the text. The theme recurs also in the authoritative Lutheran declaration of faith, Formula Concordiae, Solida Declaratio II 24, 40, 42, Die Bekenntnisschriften, Band 2, 882, 888.

${ }^{107}$ Cat. min. II 6: "Ich gläube, daß [...] der heilige Geist hat mich durchs Evangelion berufen, mit seinen Gaben erleuchtet, im rechten Glauben geheiliget und erhalten, gleichwie er die
} 
In the German text of the Großer Katechismus, the author explains this role of the Spirit further, explicitly placing it in an ecclesial context. Echoing Basil's image of the Church as a mother who gives birth to children ${ }^{108}$, Luther maintains that in this world, the Spirit has a special "Gemeine," "the mother" who begets and bears every Christian through the Spirit-revealed word. The Spirit also enlightens and ignites hearts to understand and accept this word. ${ }^{109}$ Here, the reformer appears to imply that all of this occurs in the context of the Christian community, into which believers are thus also grafted. Thereafter, they are no longer outside of the realm of the Spirit, i.e., the Church, but inside it. If only Luther's "word" is taken in the Basilian sense of corporately handing down the Christian faith, then the strong resemblance between the two writers' understanding of the ecclesial and initiatory nature of spiritual illumination becomes evident.

The enlightening work of the Spirit is commonly also briefly brought up in the writings of Luther's theological heirs. However, even with these perfunctory gestures towards to the reformer's work, it seems altogether customary to offer little more than short overviews of this theme. ${ }^{110}$ Furthermore, and curiously, even in classic Lutheran studies from the 20th century that delve somewhat deeper into the notion of spiritual illumination, a thorough articulation of the ecclesiological dimensions of this theme has been left wanting. ${ }^{111}$ Considering the central position of this image in the ecclesiology of Luther's catechisms, this tendency seems rather surprising.

ganze Christenheit auf Erden berüft, sammlet, erleucht, heiliget und bei Jesu Christo erhält im rechten einigen Glauben.” In the Latin, the words relevant for this study are rendered thus: "spiritus sanctus per evangelium me vocavit, suis donis illuminavit, recta fide sanctificavit et conservavit, quemadmodum solet totam ecclesiam in terra vocare, congregare, illuminare, sanctificare et in Jesu Christo per rectam unicam fidem conservare." The English translation is from Luther's Small Catechism with Explanation (Saint Louis: Concordia Publishing House, 1986), 17. The emphases are my own.

${ }^{108}$ Exh. bap. 1, PG 31, 425.

${ }^{109}$ Cat. maj. II 42, Die Bekenntnisschriften, Band 2, 655; see also: II 66, ibidem, 661.

${ }^{110}$ See e.g.: Hermann Sasse, "On the Doctrine of the Holy Spirit: Letters to Lutheran Pastors, No. 51, July/August 1960," in We Confess: The Church. We Confess Anthology, trans. Norman Nagel (St. Louis: Concordia Publishing House, 1999), 25; John T. Pless, Praying Luther's Small Catechism: The Pattern of Sound Words (Saint Louis: Concordia Publishing House, 2016), 50.

${ }^{111}$ E.g. Peters, Kommentar zu Luthers Katechismen, 194-95, 200-4, 206-7; Edward W. A. Koehler, A Short Explanation of Dr. Martin Luther's Small Catechism (Fort Wayne, Indiana: Concordia Theological Seminary Press, 1981), 183-85; Adolf Hoenecke, Ev.-Luth. Dogmatik: Band 3. Die eigentliche Dogmatik. Soteriologie (Milwaukee, Wis.: Northwestern Publishing House, 1912), 246-55; R. Pieper, Der Kleine Katechismus Luthers aus der heiligen Schrift und Luthers Werken in exegetisch-dogmatischen Vorträgen (Milwaukee, Wis.: Germania Publishing Co., 1901), 81-96. For Luther's view on spiritual illumination prior to the writ- 
I suggest future studies of Lutheran dogmatics would be greatly enriched were the theme of spiritual illumination to be reintroduced into the ecclesiological context in which it was dealt with, not only by Eastern fathers such as Basil, but also by the reformer himself.

Moreover, a thorough examination of the extent and depth of the parallel positions by these two writers could prove to be helpful in both identifying and cracking ajar another possible door to ecumenical dialogue between the contemporary proponents of the illuminatory concepts of Basil - such as many of the Eastern Orthodox - and Luther - such as Church bodies that subscribe to the Lutheran confessional documents. ${ }^{112}$ This would be timely, for while pneumatology and the work of the Spirit have been central themes of Lutheran-Orthodox discussions in recent decades, the noteworthy resemblance and ecclesiological significance of both parties' illuminatory concepts has hardly been examined thoroughly. ${ }^{113}$ Of course, in such bilater-

ing of the Catechisms, see: Veikko Ilmari Karimies, "In your Light we see the Light: Martin Luther's Understanding of Faith and Reality between 1513 and 1521" (ThD diss., University of Helsinki, 2017), hdl.handle.net/, accessed March 31, 2020.

${ }^{112}$ Evidently, comparing Basil and Luther is by no means a novel method for ecumenical dialogue between Eastern Orthodox and Lutheran theologians, see e.g.: Hans Friedrich Geißer, "Das Wirken des Heiligen Geistes in der Predigt des Evangeliums und der Feier der Sakramente," in Das Wirken des Heiligen Geistes in der Erfahrung der Kirche: Achter bilateraler theologischer Dialog zwischen dem Ökumenischen Patriarchat von Konstantinopel und der Evangelischen Kirche in Deutschland vom 28. September bis 7. Oktober 1987 in Hohenwart, Studienheft 21, eds. Heinz Joachim Held and Klaus Schwarz (Missionshandlung Hermannsburg, 1995). For other examples of Orthodox use of Basil as an authority in ecumenical dialogue, see e.g.: Archbishop Mikhail (Mudjugin), "Holiness, Sanctification, Saints," in Mikkeli 1986: The Seventh Theological Conversations between the EvangelicalLutheran Church of Finland and the Russian Orthodox Church, Mikkeli, June $3^{\text {rd }}-11$ th 1986, ed. Hannu T. Kamppuri, Publications of Luther-Agricola Society 16 (Helsinki: LutherAgricola Society, 1986), 63-64; Liverij Voronov, "Taufe und Zugehörigkeit zur Kirche im Blick auf den Stand des Ungetaufen," in Taufe-Neues Leben-Dienst: Das Leningrader Gespräch über die Verantwortung der Christen für die Welt zwischen Vertretern der Evangelischen Kirche in Deutschland und der Russischen Orthodoxen Kirche, Studienheft 6 (Witten: LutherVerlag, 1970), 84, 86, 88; N. Uspenskij, "Das rettende und heiligende Wirken Gottes durch den Heiligen Geist im Gottesdienst und in den Sakramenten," in Vom Wirken des Heiligen Geistes: Das Sagorker Gespräch über Gottesdienst, Sakramente und Synoden, zwischen Vertretern der Evangelischen Kirche in Deutschland und der Russischen Orthodoxen Kirche, Studienheft 4 (Witten: Luther-Verlag, 1964), 58-61.

${ }^{113}$ Commenting on "the first attempt at a common expression of soteriology at the global level," the 1995 Lutheran-Orthodox Limassol statement, Risto Saarinen even maintains that "the use [in the statement] of the triad purification-illumination-glorification [...] is new for Lutherans." See: Saarinen, "Salvation in the Lutheran-Orthodox Dialogue: A Comparative Perspective," in Union with Christ: The New Finnish Interpretation of Luther, eds. Carl E. Braaten and Robert W. Jenson (Grand Rapids, Michigan-Cambridge, U.K.: William B. Eerdmans Publishing Company, 1998), 179-80. In light of the illumination terminology of the Lutheran catechisms, it seems surprising that, as articulated in the 1998 statement 
al discussions one would have to take into account not only the well-known dispute between the East and West about the reception of Creeds and their versions ${ }^{114}$, but also minute differences in the interpretation of spiritual illumination. For instance, whereas Basil and other Eastern Patristic authors identify illumination with baptism ${ }^{115}$, Luther and many of his followers feel the need to emphasize the centrality of the word as the medium of the Holy Spirit. And thus, the latter were led to regard the word as the primary medium of spiritual illumination. ${ }^{116}$ After noting this, it may also be beneficial to consider the following: Rather than promoting a strictly word-centered, kerygmatic ecclesiology attributed to many protestant bodies ${ }^{117}$, the confessional documents of the Lutheran Liber Concordiae unanimously maintain that the Spirit-filled word is the very element that renders baptismal water a salvific means of grace. ${ }^{118}$ If this position - subscribed to by most, if not all, Lutheran churches, and reminiscent also of Basil's baptismal theology, according to which "the voice of the Lord is upon the waters" 119 - were to be taken into account, reconciliation of the illuminatory concepts of the Eastern and Western parties might not be beyond the realm of possibility.

of the Lutheran-Orthodox Joint Commission, "[ $\mathrm{t}]$ his terminology has not been central in Lutheran tradition.” See: lutheranworld.org/sites/default/files/1998-Lutheran_Orthodox_ Dialogue/, accessed July 9, 2020. Certainly, the illumination terminology of Lutheran confessional writings does occasionally appear in the documents of ecumenical dialogue, see e.g.: lutheranworld.org/sites/default/files/1985-1987-1989-Lutheran_Orthodox_Dialogue/, accessed July 9, 2020; H. F. Geißer, "Das Wirken des Heiligen Geistes," 30-31, 33, 35, 39-40. Despite these references, however, the obvious similarities between the Basilian and Lutheran notions of illumination and Church membership remain uncovered, even when Basil and Luther are employed side by side.

${ }^{114}$ For discussion on the history of one of the most disputed topics, the filioque, see: John N. D. Kelly, Early Christian Creeds (London: Longmans, Green and Co Ltd, 1960), 301, 354-55, 358-67, 407, 409-10.

${ }^{115}$ See n. 40 above. For modern examples of the same doctrine, see: Rommen, Being the Church, 98-99; Alexander Schmemann, Of Water \& the Spirit: A Liturgical Study of Baptism (Crestwood, New York: St Vladimir's Seminary Press, 1974), 42-43.

${ }^{116}$ For Luther's view, see e.g. WA 42, 321-2; W²XIIIa, 232-3. See also: Cat. maj. III 5152, Die Bekenntnisschriften, Band 2, 673; Formula Concordiae, Solida Declaratio XI 29, 34, 40, ibidem, 1072, 1074-75. For discussion on the word as the means of illumination in Gerhard, Quenstedt, and other prominent Lutheran theologians of the 17th century, see: Robert Preus, Inspiration of Scripture: A Study of the Theology of the $17^{\text {th }}$-century Lutheran Dogmaticians (Saint Louis: Concordia Publishing House, 1957), 171-73, 177, 182-85, 190. A similar idea is explicated also in Lutheran dogmaticians of the 19th and 20th century, see: Pieper, Der Kleine Katechismus Luthers, 85, 89-90; Hoenecke, Ev.-Luth. Dogmatik, 246-50.

${ }_{117}$ Cf. Dulles, Models of the Church, 68.

118 Schmalkaldische Artikel III 5, 1-3, Die Bekenntnisschriften, Band 1, 449-50; Cat. min. IV 1-2, 9-10, ibidem, 515-16; Cat. maj. IV passim, Die Bekenntnisschriften, Band 2, 691-707.

${ }^{119}$ In Ps. 28.3, PG 29, 289. 
Obviously, pushing the aforementioned ecumenical door ajar and then flinging it open is a task that must be left for another time. In order to accomplish this task, however, we have to be aware that the door itself is there. The foregoing may serve as a brief indication of its location.

\section{Concluding remarks}

While scholarship has given ample attention to Basil of Caesarea's notions of light and illumination on the one hand, and the Church and its membership on the other, until now these two themes have hardly been analyzed together. In this article, I have attempted to show that in De Spiritu Sancto, participation in divine light is not only in direct relation to Church membership, but that these two themes are actually equated with each other - if membership is understood in the fundamental and holistic sense of the word, including both spiritual and sociological aspects. Arising from this, the main findings can be summarized in five points.

First, in Basil's rhetoric, the imagery of light is more than a means of describing the indescribable God, who is the one, simple, and eternal source of life and goodness. For the author, images of light and illumination represent restoration to life in full humanity, seeing and being seen, participation, communion, and being "inside". This is first implied by the way Basil uses the imagery of light in reference to the Persons of the Trinity and their mutual relations, and secondly in the way he uses the imagery to depict the spiritual union between the Divine, the individual, and the Christian community as a whole. The Basilian view of divine illumination may be described as a "drawing in" of these persons to communion with the Trinity.

In the same vein, Basil also uses the image of darkness as a means of describing life without the illumination of the Spirit, the consequent ignorance of God, and ultimate condemnation. For the Caesarean, darkness appears to represent incognizance of both the Divine and oneself, nonparticipation, individualism, and being "outside". This view is underscored by the way Basil discusses life "outside of" the Spirit using Biblical vocabulary that is commonly employed in reference to those outside of the Church.

Second, Basil's concept of Church membership can be defined as corporate participation in the divine life of the Trinity, through the gracious activity of the Holy Spirit. As a consequence of this mystical union with the Divine, believers enter into fellowship with each other as well. In this way, Church membership is fundamentally spiritual reality, but it also has sociological aspects.

Third, in Basil's view, participation in divine light is an ecclesial mystery. Its ecclesial nature is evident from the way this participation is bestowed 
upon individuals, and also from the reality into which this bestowal transfers them. Participation in divine light is bestowed in Christian initiation, i.e., in the corporate acts of handing down the Christian faith in baptismal instruction, and thereafter, the rite of baptism itself. Through this ecclesial process, individuals receive spiritual illumination, i.e., knowledge of God. Put differently, they are received into communion with the light that is the Divinity. Synchronously, they are incorporated into the community of the other similarly illuminated Christians. Thus, bestowed in Christian initiation, divine light affects the lives of - or is the life of - those who participate in it. This light connects each member of the Church with the Divinity Himself, and also makes them participants of each other as well.

Fourth, ecclesial participation in divine light produces ecclesial, outward expressions. One of these is worship. According to Basil, the Spirit gathers individuals together, and forms them into one worshiping community. Therefore, worship can occur solely in the context of the Church. Moreover, participation in spiritual light forges Christians into intermediaries of this light. In Basil's account, this pertains to individual believers as well as to the whole Church. By virtue of their participation in divine light, the clerics act as illuminators of souls within the congregation. Similarly, as partakers of "the true light of the world," the whole congregation acts as the light of the world, sharing the light of divine understanding not only with each other, but with those outside in the world as well.

Fifth, in addition to shedding new light on the Basilian notion of Church membership, the present study indicates one potential topic of ecumenical dialogue on ecclesiology between the Orthodox Church and Lutheran Church bodies. I have argued that there is a striking resemblance between the imageries of spiritual illumination presented in De Spiritu Sancto on the one hand, and in the ecclesial section of Luther's exposition of the Apostles' Creed on the other. Curiously, however, the connection between these illuminatory concepts appears insufficiently studied. Future engagement with this connection would be helpful in two ways: It would not only enrich (the profoundly) Lutheran understanding of the spiritual aspect of Church membership, but it would also help open a passage to a mutual understanding of the mystery of Church membership between the followers of the Eastern and Western interpretations of spiritual illumination.

Finally, I venture to suggest that Basilian scholarship would benefit from a broader exposition of this present topic. In a larger study, one could draw evidence from the entire Basilian corpus and investigate the following question: If, in De Spiritu Sancto, the ecclesial rites of initiation are the ultimate means of participatory relationship between the human being and 


\section{Harri Huovinen}

the Divine, and if this participation results in the ecclesial acts of corporate worship and public witness, why is the eucharist - the sacrament of participation par excellence and the fulfilment of the Church - absent from Basil's exposition of illuminatory participation? Considering that along with baptism, the eucharist constitutes one of the key questions of modern ecumenics, a deeper look into this issue could prove helpful in opening up yet another door to a fruitful dialogue on the mystico-sacramental reality relevant to all Christians from all churches, that is, Church membership. 